\title{
RFID in the Supply Chain: Lessons from European Early Adopters
}

\author{
Andrew White BSc MSc EngD FRSA \\ Said Business School \\ University of Oxford \\ Egrove Park \\ OXFORD \\ OX1 5NY \\ United Kingdom \\ $\mathrm{T}:+44(0) 1865422712$ or $+44(0) 1865422500$ \\ F: $+44(0) 1865422501$ \\ E: andrew.white@sbs.ox.ac.uk, \\ W: www.sbs.ox.ac.uk
}

\author{
Mark Johnson BEng MSc EngD MIEE \\ Supply Chain Research Centre \\ Cranfield School of Management \\ Cranfield \\ Bedfordshire \\ MK43 0AL \\ UK \\ T: $+44(0) 1234754935$ \\ F: +44 (0) 1234751806 \\ E: mark.johnson@cranfield.ac.uk
}

Hugh Wilson MA(Oxon) DipCompSci(Cantab) PhD

Director, Centre for Customer Management

Cranfield School of Management

Cranfield

Bedfordshire

MK43 0AL

UK

T: $+44(0) 1234751122$

F: +44 (0) 1234751806

E: hugh.wilson@cranfield.ac.uk

\section{Type of Paper: Research paper}




\begin{abstract}
Purpose

Radio frequency identification (RFID) is increasingly being presented as a technology with the potential to improve supply chain performance, but empirical evidence from early adopters is sparse. This paper aims to rectify this scarcity and contribute to a more informed discussion in and between academic and practitioner communities.

Design/Methodology/Approach

The paper is based on a conceptual model of factors influencing the success of adoption efforts. It then reports the results of a survey of 612 European supply chain managers, focusing on the 128 respondents who have begun RFID trials.

Findings

A significant influence on operational deployment is the presence of mandates from key customers requiring the technology's use. Customer mandates also impact the anticipated benefits of a faster sales cycle and of enhanced systems integration, though the relationships are complex. By contrast, greater cost reduction benefits are anticipated in two industries where mandates are less common - industrial goods and logistics. Perceived organizational innovativeness positively impacts anticipated ROI from RFID. Companies adopting a 'slap and ship' approach are less likely to anticipate pricing benefits than those integrating RFID into enterprise systems
\end{abstract}

\title{
Research Limitations/Implications
}

The limitations of the paper include the limited sample size of early adopters. In addition, qualitative research is needed into RFID supply chain applications and into different approaches to IS integration of RFID, to inform future survey work.

\section{Practical Implications}

This paper informs supply chain managers and senior decision makers who are examining the potential of RFID technology. It offers guidance on what issues to look for when adopting this technology, approaches to take and the benefits that might be accrued.

\section{Originality/Valuer}

This paper offers a major contribution to understanding the current status of the adoption of RFID in European supply chains. This understanding is put in the context of the wider literatures on supply chain management and the adoption of information systems and technology. 


\section{INTRODUCTION}

Effective supply chain management is increasingly being seen as a key determinant of an organization's competitive advantage. Unacceptable levels of on-shelf availability in retail stores (Fisher, 1997), reports of poor customer service by manufacturers and logistics companies (Lee, 2002) and excessively high inventory levels (Lee and Billington, 1992) are all manifestations of less then optimized levels of supply chain performance. This need for improved performance is being exacerbated by the increased globalization of sources of supply, the outsourcing of business processes such as manufacturing and logistics, and the increased service orientation of many manufacturing organizations (Feenstra, 1998; Wise and Baumgartner, 1999; Christopher, 2004). These factors, coupled with the estimate that more than $50 \%$ of the waste in extended supply chain processes occurs between enterprises or beyond the edge of the enterprise (Dominy, 2003), is causing many to believe that competition can be between supply chains as well as individual organizations (Christopher, 1998).

Until recently, the role of information systems in improving supply chain management was constrained by geographical and temporal boundaries and by the separation of material and information flows across a supply chain (Breu and White, 2004). These constraints inhibited "any where, any time" access to data and applications, and prevented human agents within an organization from responding in real time to supply chain events (McFarlane and Sheffi, 2003). The separation of physical and information assets created what has been termed 'dumb' physical assets (White, et al. 2004). Some commentators have suggested that the adoption of Radio Frequency Identification (RFID) technology promises to mitigate this structural deficiency, and hence to improve management of the supply chain (Sheffi, 2004). As adoption increases, there is a need to begin to complement this speculation with empirical evidence, and fulfil an important part of the research agenda into e-business logistics (Auramo, et al . 2002, Cavinato, 2005).

This paper therefore reports on a survey conducted with 616 European supply chain managers, and specifically focuses on the experiences of the 128 respondents who are early RFID adopters, exploring the factors that determine successful perceived outcomes. These results contribute to both theory and practice, with the aim of moving the debate beyond some of the hyperbole that surrounds this technology and towards a clearer understanding of its role in the management of supply chains. First, we will review the previous literature which hypothesizes what this role is.

\section{IS AND RFID IN THE SUPPLY CHAIN}

The important role that information systems play in the management of supply chains has been repeatedly highlighted in the literature. Previous research has indicated, for example, the impact of information systems in increasing the efficiency of supply chains (Alkadi et al., 2003), in aligning supply chain strategy and business strategy (Williams et al., 1997), and in contributing to overall organizational growth and profitability (Kotha and Swamidass, 2000; Byrd and Davidson, 2003). On an operational level, the adoption of information systems has been linked to an increase in product offerings and customer service levels (Kincade et al., 2001), and to improved quality and timeliness of 
production information (Brandyberry et al., 1999), while Kent and Mentzner (2003) found that the extent of trading partners' technology adoption positively impacted the supply chain relationship between the two parties.

In order to consider the potential contribution of RFID to this picture, we will first describe the technology briefly. The main components of RFID technology are tags and readers: electronic tags which contain memory and an antenna, and readers that can read the data stored on the tag. If a tag is attached to a product, and an Electronic Product Code (EPC) - a unique product identifier based on standards developed by the EPCglobal Network - is stored on it, then the product takes on a unique electronic identity. With RFID, physical and information flows can therefore converge to create intelligent physical assets. So no longer are assets such as plasma televisions, pallets or shipping containers "dumb", unable to understand who they are or where they are, and lacking the ability to communicate this information to a third party. Instead, when they pass into (for example) a retail store or distribution centre, they can communicate their identity and history to the readers located by the loading bays, and hence to the systems into which these readers are integrated.

Retailers such as Wal-Mart, Metro, Tesco, Marks \& Spencer and Carrefour have announced initiatives to use the technology, and some have mandated that their suppliers should use tagged reusable assets for the products that they supply (Sullivan, 2004). Manufacturing companies such as Airbus have started to use RFID to track spare parts (LogicaCMG, 2004), and BMW is tracking cars as they move through the production line (Maselli, 2004). Many of the major IT vendors, such as IBM, SAP and Oracle, have announced strategies to adapt existing solutions to exploit RFID, and the technology has also been the focus of attention by national and international bodies, with the EU funding a number of research projects in this area. When viewed collectively, it is apparent that there are major developments being undertaken by various categories of powerful actors. This is creating an expectation that there will be widespread adoption of this technology, and that it will have a noticeable impact on the performance of supply chains.

From a supply chain management and operations perspective, this is a field of research and practice where the latter has very much led the former. Extensive literatures exist concerning the technical aspects of RFID technology (e.g. Frisk et al. 2002; Knospe and Pohl 2004; Rasul 2004; Yagi et al. 2005) but little is known about the current state of adoption of RFID technology in a supply chain management context. That which has been published is largely anecdotal and case based (Angeles 2005; Jones et al, 2004; Ault 2004; Atkinson 2004). The time seems ripe, therefore, to explore the experience of early adopters.

\section{CONCEPTUAL MODEL}

Our conceptual model is presented as Figure 1. The model considers the case of an organization which has made at least initial steps towards RFID adoption, typically through an RFID trial, and is concerned with factors influencing the perceived success of this adoption. It consists of two key components: factors that determine the outcomes of RFID adoption; and the outcomes themselves, which we will consider first. 


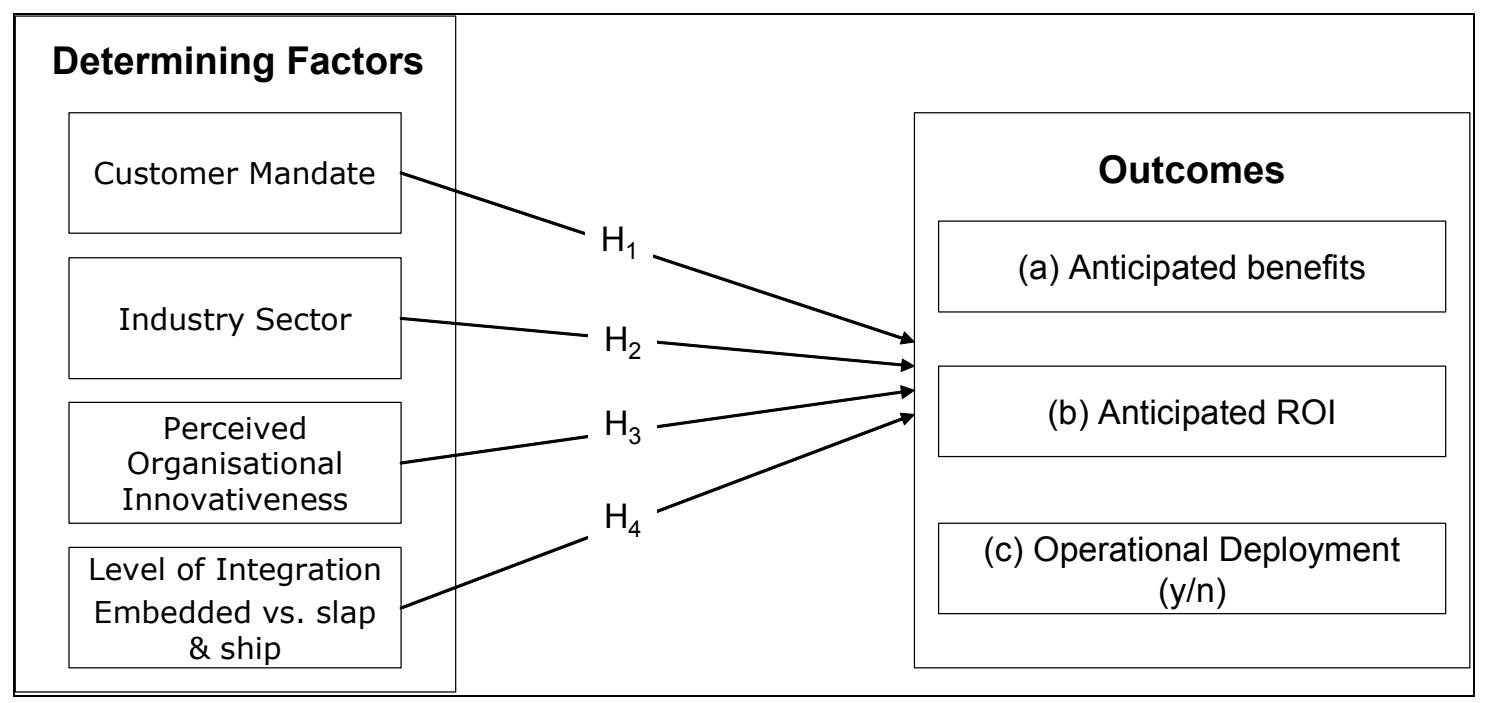

Figure 1 RFID adoption conceptual model

The need for IT investments to generate a return on investment is well established (Tiernan and Peppard, 2004). Many researchers also examine the specific benefits that can be attributed to a technology (Lee, 2001; Kearns, 2004). Research from practitioner organizations such as consultancies, investment banks and analysts has suggested what these benefits might be in the case of RFID. For example, Accenture (2004) suggests that benefits will come from improved finished goods inventory, production visibility and supply chain planning activities, while analyst Juniper (2005) anticipates benefits including reduced counterfeiting, process improvements in areas such as track and trace, and reduced theft or shrinkage. We therefore include in the conceptual model each of ROI (labeled (b) in Figure I), anticipated benefits (labeled (a)) and operational deployment (labeled (c)). The use of anticipated as opposed to achieved perceived benefits reflects the early stage of adoption in most organizations. The perceived benefits in the model, which are shown as column headings in Table III, have been developed from extant literature and are presented below.

The issuing of mandates by large retailers such as Wal-Mart and Target means that 'many of these suppliers have no choice' but to adopt this technology if they are to win new or keep existing business (Vijayaraman and Osyk, 2006). The structuring of these mandates is reported to vary by issuing organisation. For example, The US Department of Defence is paying for the costs incurred in complying with the mandate, whereas it is estimated to cost Wal-Mart's top 125 vendors $\$ 500 \mathrm{~m}$ to do so (Twist, 2005). Other examples of how mandates differ include the type of tag and the type of asset (for example, a pallet or an actual product) or stock-keeping unit to be tagged. The second perceived benefit, improved customer service, is linked to the concept of mandates. Parasuraman et al. (1984) define customer service as a comparison of customer expectations with the performance of the organization as perceived by the customer. Operations that are enabled with RFID may enable suppliers to meet existing and/or raised expectations of customers in areas such as baggage handling by airlines (Wyld, et al. 2005) and product authenticity (Jones, et al. 2005). 
The challenge of holding enough inventories to meet demand, but not incur excess cost, is a perennial supply chain management problem (Forrester, 1961; Lee, et al. 1997). Chow, et al. (2007) found (on a single case study basis) that by applying RFID to a supply chain, along with other enabling technologies, significant reductions in inventory levels (without a corresponding drop in out-of-stocks) were found. Hence the next hypothesized benefit of reduced inventory. However, the ability to supply (i.e. holding inventory) is not sufficient to fulfill a customer order. The next perceived benefit of having a faster sales cycle is also necessary (Ellram, et al. 1989). With increased visibility of stock enabled by RFID leading to possible availability of it in the right place, we postulate that adopting organizations can produce faster sales cycle times (from order to fulfillment).

Reducing supply chain costs by applying RFID has been suggested as one of the main benefits of this technology (Attaran, 2007). The types of costs that can be reduced include: redirecting products originally intended for one location to another; using alternative transportation modes; changing the product mix in production; reallocating products to different supply chains; and using pricing and rebates to affect product demand and product substitution (Lin, et al. 2006). RFID has not just been positioned as a technology to lower the cost of supply chain operations, though, but also to improve the value that is produced for customers. Nagumo (2003) identifies a number of prototype products and services in areas such as healthcare, concierge and road pricing that are being transformed by the use of RFID. It is arguable that the perceived benefit of higher prices being charged could result from this value-adding activity.

It seems plausible that any of these perceived benefits of RFID may be order winners or order qualifiers: over time those benefits that had been considered winners would be expected to migrate to becoming 'hygiene factors'. Therefore, as a further benefits measure, we add perceived impact on competitive advantage. Finally, we have already discussed how the management of supply chains has been constrained by geographical and temporal boundaries and by the separation of material and information flows across a supply chain (Breu and White, 2004), preventing human agents from responding in real time to supply chain events (McFarlane and Sheffi, 2003). The integration of RFID of information systems integration, due to one intelligent asset being able to talk to two information systems within and across organisations, may provide a further benefit to supply chain management.

One of the major challenges that adopters of RFID have been faced with is whether or not their investments in the technology will generate a positive return on investment (Miller, 2007). This is a critical benefit for adopters of the technology to realise in itself, but also if the final type of outcome, that of operational deployment, is to be realized. Given that trialability is a key factor determining the eventual adoption of an innovation (Rogers, 2003), an adopting organization progressing beyond a trial to where the technology is deployed as part of its everyday operations is a primary indicator as to its perceived value. Therefore, whether or not RFID has been operationally deployed is the third outcome measure in this study. 


\section{Determining Factors \\ Customer Mandates}

The optionality or otherwise of an innovation has unsurprisingly been shown to be an instrumental factor in the diffusion of a range of innovations (Rogers, 2003). In the case of RFID, several major buyers of both consumer and non-consumer goods have mandated that their major suppliers adopt the technology as a necessary component, or "order qualifier", of their commercial relationship. In the US, these mandating organizations include Wal-Mart and the Department of Defense (Asif and Mandiwalla, 2005), while in the EU, retailers such as Tesco in the UK and Metro in Germany (Juniper, 2005) have announced similar initiatives. We conceptualize RFID adoption in response to these mandates as driven by customer service, which can be defined as a comparison of customer expectations with the performance of the organization as perceived by the customer (Parasuraman et al., 1984). Any RFID adoption in response to such a mandate may mean an increase in the cost to serve the mandating customer, and may have limited planned benefits other than maintaining revenue levels derived from current customers, which may result in a limited expectation of such additional benefits in the future. In addition, those responding to the mandate will have less discretion to decide not to proceed with full operational deployment of the technology than those whose decision depends on results from the trial alone. The leads to the following set of hypotheses:

$\mathrm{H}_{1 \mathrm{a}}$ - Organizations who have adopted RFID technology in response to a mandate from their customers will have lower anticipated benefits than those who have not received a mandate.

$\mathrm{H}_{1 \mathrm{~b}}$ - Organizations who have adopted RFID technology in response to a mandate from their customers will have a lower anticipated return on investment than those who have not received a mandate.

$\mathrm{H}_{1 \mathrm{c}}$ - Responding to a mandate from customers will positively determine whether organizations have progressed beyond a trial to operational deployment of RFID.

\section{Industry Sector}

Industry sectors are known to possess different characteristics such as the bargaining power of suppliers and buyers, and barriers to entry (Porter, 1980). In the context of the adoption of information technology, factors such as typical organization size, position in the value chain, country of location and IT infrastructure of an industry (Clarke, 1992), and the nature of products and how they are purchased (Malone et al. 1987) have all been suggested to be determining factors. Therefore we conceptualize that the industry in which an organization resides has a determining role in the level of RFID adoption. The leads to the following set of hypotheses:

$\mathrm{H}_{2 \mathrm{a}}$ - The anticipated benefits derived from adopting RFID technology will be determined by the industry sector in which the organization resides.

$\mathrm{H}_{2 \mathrm{~b}}$ - The anticipated return on investment derived from adopting RFID technology will be determined by the industry sector in which the organization resides.

$\mathrm{H}_{2 \mathrm{c}}$ - The decision to adopt RFID operationally will be determined by the industry sector in which the organization resides. 


\section{Perceived Organizational Innovativeness}

The ability of an organization to assimilate new technology into its operations has been shown to be dependent on its innovative capability (Avlonitis et al. 1994; Tang 1999; Hult et al. 2004). Organizations that possess these capabilities are often referred to as "early adopters", and are seen as a source of advice and information about innovations (Rogers, 2003). In the context of RFID, understanding whether these early adopters are deriving greater benefits from the technology is essential in understanding the characteristics of its diffusion. This rationale suggests the following hypotheses:

$\mathrm{H}_{3 \mathrm{a}}$ - The anticipated benefits from adopting RFID technology will be dependent on the perceived innovativeness of the adopting organization.

$\mathrm{H}_{3 b}$ - The anticipated return on investment of RFID technology will be dependent on the perceived innovativeness of the adopting organization.

$\mathrm{H}_{3 \mathrm{c}}$ - The decision to adopt RFID operationally will be dependent on the perceived innovativeness of the adopting organization.

\section{Level of Integration}

The use of RFID to track individual products, pallets or containers allows data to be collected on such issues as movements across specific geographic boundaries, and when and by whom an asset was last serviced. In order to make sense of the data generated by the tags and readers, integration must be in place with the wider enterprise information systems and the business processes that these systems enable. For example, if a tagged pallet is loaded onto a truck, a RFID reader located on the loading bay could inform both the warehouse management system that the goods have been dispatched, and also the financial system that a transaction has occurred and that an invoice needs to be issued. This need for integration between different systems is reflected in the wider literature concerning the use of intra- and inter-organizational information systems. Integration of systems with the wider IS infrastructure has been found to affect the return on investment generated from ERP system implementation (Themistocleous et al. 2001), time-based performance of the supply chain (Jayaram et al. 2000), and the ability of "real-time information to travel immediately backwards" so that "inventory flows swiftly forwards" (Frohlich, 2002). IS integration can be regarded as encompassing processes, programs and data repositories (Yang and Papazoglou, 2000). However, the ease with which this integration can be accomplished should not be underestimated in terms of cost, management time and complexity (Gunasekaran and Ngai, 2004). This point suggests that it may be easier to adopt information technologies when their integration into the wider information system infrastructure is not an explicit part of this adoption process, although this approach may not deliver the same degree of benefits.

These discussions of IS integration are also apparent in literature to date on RFID specifically. It has been suggested that two principal types of RFID adoption strategy are being employed (Aberdeen Group, 2004), with a third which is positioned part way between these two extremes. At one extreme is 'slap and ship', which involves placing an RFID tag on an asset and then shipping it to a third party for it to use in its own information systems. At the other is the integration of RFID with the wider enterprise systems of the adopting organization. This is referred to as 'embedded', and means that 
data from the tags is being analyzed in supply chain, enterprise resource and CRM systems, and decisions made as a result of this analysis at multiple points of the organization. There may be some organizations, for example those serving multiple retailers and therefore under multiple mandates, who are using a combination of the two approaches. This is referred to as 'hybrid', and could also be due to where the adopting organization perceives that an ROI could be generated from the use of the technology with specific products. The leads to the following set of hypotheses:

$\mathrm{H}_{4 \mathrm{a}}$ - Organizations employing a slap and ship adoption strategy will have lower anticipated benefits than those integrating the RFID technology with their existing information systems.

$\mathrm{H}_{4 b}$ Organizations employing a slap and ship adoption strategy will have lower anticipated return on investment than those integrating the RFID technology with their existing information systems.

$\mathrm{H}_{4 \mathrm{c}}$ - A greater proportion of organizations that have adopted a slap and ship adoption strategy will have progressed beyond a trial to operational deployment than those organizations that have an integrated approach.

\section{METHOD}

Following adoption studies in other domains (Ellram, 1996), a cross-sectional survey approach to hypothesis testing was used. Telephone interviews were used in order to reach a large number of senior management respondents (Biemer and Lybergy, 2003).

\section{Measures}

Customer mandating was measured through an item with four categories: those already using a mandate; those currently required to fulfil a mandate at a specified future date; a customer mandate being anticipated but not yet in force; and no customer mandate being anticipated. The industry sector classification used was retailing; transport, distribution and logistics; manufacturers of consumer goods including food and drink; and industrial manufacturers. Organizational innovativeness was assessed by the respondent's perception, and measured by a five-point item whose categories are described in Table III. The terms used in the study to define an organization's approach to adopting innovative technologies/approaches are: 'early adopter', an organization that seeks to be among the first to adopt new technology; 'fast follower' organizations that are deliberately not first, but recognize the value of new technology and seek to learn from the mistakes of the early adopters and quickly exploit the technology; 'cautious followers', those who need plenty of reassurance of the benefits of the technology from adopters similar to themselves; and finally, the 'cautiously agnostic' who have little explicit or implicit strategy to adopt new technology and wait until a substantial majority of similar organizations have adopted the technology (Rogers, 2003; O’Neill et al., 1998). The respondent was asked to self-assess which of these labels best described their organisation's approach to the adoption of technology.

The level of integration was measured by a categorical variable with three values: full integration; 'slap and ship'; and hybrid, or partial integration. The respondent was asked which of three categories best described their organisation's RFID adoption, with the categories briefly defined to the respondent as: "A fully integrated and embedded system which placed RFID at the heart of the company's systems and processes"; "A 'slap and 
ship' solution fulfilling the mandate but lacking an internal role"; and "Somewhere between embedded RFID and 'slap and ship' ".

The outcome variables were measured as follows. Operational deployment was measured by a seven-category item ranging from operational deployment (1) to no plans for a trial (7), as shown in Table I. Anticipated return on investment was measured by a three-point item ranging from skepticism to optimism about the anticipated ROI. Anticipated benefits were measured by ordinal variables consisting of 1 ('major reason'); 2 ('minor reason'); and 3 ('not applicable') for each of 10 potential benefits synthesized from the available academic and practitioner literatures (Jayaram, et al. 2000, King, 2002, Accenture 2004; Juniper 2005), and listed in Table III.

\section{Sample frame}

The population for the survey was supply chain managers within European organizations from four industrial sectors: retailing; transport, distribution and logistics; manufacturers of consumer goods including food and drink; and industrial manufacturers. The survey organizations were selected randomly from Supply Chain Europe and Dun and Bradstreet databases and the survey was administered anonymously by telephone by native speakers. Table I displays the responses, stratified according to country of response and status of RFID technology usage within the respondent's organization. There were 612 responses to the survey, with the 128 organizations having exposure to the use of RFID technology within their organization (trial under way or higher for the operational deployment scale) being classified as the 'early adopters' and focused on in this paper. It should be noted that whilst Table I indicates that there is a significant weighting towards the UK in the sample, many of the organizations surveyed operated in multiple countries. Administration of data collection was carried out by a market research agency, and information is not available on the number of managers contacted by telephone who declined to participate; furthermore, assessing non-response bias by comparing late respondents to early ones ( $\mathrm{Li}$ and Calantone 1998) cannot be carried out with this method of data collection. For this reason and also due to the sampling from the subscribers to a practitioner publication Supply Chain Europe, the achieved sample should be regarded as a convenience sample with the possibility of bias relative to the population.

\begin{tabular}{|c|c|c|c|c|c|c|c|}
\hline RFID adoption status & UK & France & Germany & Italy & Spain & Sweden & TOTAL \\
\hline Deployed & 27 & 16 & 5 & 7 & 27 & 5 & 87 \\
\hline $\begin{array}{l}\text { Successful trial but no } \\
\text { deployment }\end{array}$ & 4 & 1 & 3 & 0 & 2 & 0 & 10 \\
\hline & 1 & 1 & 0 & 0 & 3 & 0 & 5 \\
\hline $\begin{array}{l}\text { Unsuccessful trial with no } \\
\text { deployment }\end{array}$ & 2 & 0 & 0 & 0 & 1 & 1 & 4 \\
\hline Trial currently underway & 9 & 1 & 3 & 2 & 6 & 1 & 22 \\
\hline Planning a trial & 32 & 13 & 10 & 6 & 9 & 8 & 78 \\
\hline No plans for a trial & 226 & 28 & 43 & 44 & 21 & 44 & 406 \\
\hline TOTAL & 301 & 60 & 64 & 59 & 69 & 59 & 612 \\
\hline
\end{tabular}

Table I: RFID adoption status by country 
Table II provides similar descriptive data on the sample's status of RFID usage but categorized by industry sector rather than by country. The data within Table II indicates that adoption - or plans for adoption - is more prevalent within manufacturers and processors of industrial goods. Conversely, the sector with the lowest proportion of companies adopting or planning to adopt RFID technologies was the retail sector.

\begin{tabular}{|c|c|c|c|c|c|}
\hline RFID adoption status & Retail & $\begin{array}{l}\text { Manufacturer/ } \\
\text { processor of } \\
\text { consumer } \\
\text { goods }\end{array}$ & $\begin{array}{c}\text { Manufacturer } \\
\text { /processor of } \\
\text { industrial goods }\end{array}$ & $\begin{array}{l}\text { Distribution, } \\
\text { transport, logistics } \\
\text { and warehousing }\end{array}$ & TOTAL \\
\hline Deployed & 8 & 16 & 34 & 29 & 87 \\
\hline $\begin{array}{l}\text { Successful trial but no } \\
\text { deployment }\end{array}$ & 1 & 2 & 4 & 3 & 10 \\
\hline $\begin{array}{l}\text { Partly successful trial } \\
\text { with no deployment }\end{array}$ & 2 & 1 & 2 & 0 & 5 \\
\hline $\begin{array}{l}\text { Unsuccessful trial with no } \\
\text { deployment }\end{array}$ & 0 & 1 & 0 & 3 & 4 \\
\hline Trial currently underway & 1 & 4 & 8 & 9 & 22 \\
\hline Planning a trial & 8 & 18 & 22 & 30 & 76 \\
\hline No plans for a trial & 66 & 84 & 111 & 145 & 399 \\
\hline TOTAL & 85 & 125 & 177 & 214 & 601 \\
\hline
\end{tabular}

Table II: RFID adoption status by industry sector

\section{Data analysis}

As the scales within the survey were often categorical, and as the data was proven to be non-normal prior to analysis, nonparametric statistics were used. Hypotheses were tested using the Kruskal-Wallis test, the nonparametric equivalent of one-way ANOVA, as it has high statistical power (Dewberry, 2004) and is more suitable for smaller samples than parametric tests (Siegel, 1956). Item responses were coded so that responses that reported an increase in usage or benefit would result in a lower value for the mean ranks returned from the Kruskal-Wallis test. For example, the scale for anticipated return on investment (ROI) is ranked from optimistic (1) to don't know (4). A brief explanation of the interpretation of the Kruskal-Wallis test is included in the 'Notes' section at the end of this research paper.

\section{RESULTS}

Table III shows the results of the Kruskal-Wallis tests. 
PERCEIVED BENEFITS

\begin{tabular}{|c|c|c|c|c|c|c|c|c|c|c|}
\hline & 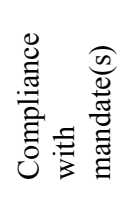 & 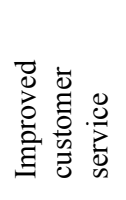 & 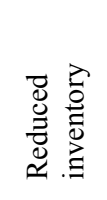 & 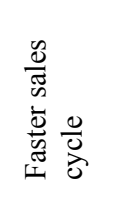 & 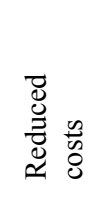 & 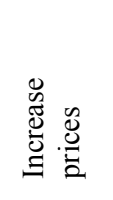 & 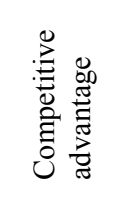 & 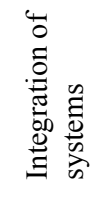 & 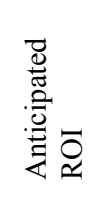 & 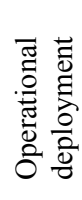 \\
\hline \multicolumn{11}{|c|}{ CUSTOMER MANDATES } \\
\hline Already using & 60.6 & 60.0 & 63.0 & 71.5 & 66.4 & 61.8 & 64.1 & 64.3 & 55.2 & 52.8 \\
\hline Now required to fulfil & 51.0 & 66.0 & 48.4 & 45.7 & 51.8 & 66.2 & 54.0 & 48.8 & 62.8 & 61.3 \\
\hline Expecting to receive & 52.2 & 59.2 & 62.9 & 50.6 & 61.1 & 56.8 & 61.2 & 50.8 & 61.6 & 78.0 \\
\hline Not anticipating & 71.8 & 65.1 & 65.3 & 65.9 & 62.9 & 65.0 & 64.0 & 70.3 & 62.0 & 67.3 \\
\hline Significance & $0.009 * *$ & 0.627 & 0.419 & $0.023^{*}$ & 0.574 & 0.769 & 0.727 & $0.014 *$ & 0.761 & $\begin{array}{l}0.01 \\
0 * *\end{array}$ \\
\hline \multicolumn{11}{|l|}{ INDUSTRY SECTOR } \\
\hline Retail & 80.1 & 63.5 & 57.1 & 56.9 & 77.0 & 65.1 & 64.0 & 51.3 & 51.6 & 62.2 \\
\hline Consumer goods & 54.3 & 59.7 & 58.5 & 60.0 & 75.5 & 53.3 & 69.8 & 57.2 & 65.7 & 63.8 \\
\hline Industrial goods & 63.2 & 64.1 & 59.5 & 62.6 & 57.6 & 64.5 & 59.1 & 61.9 & 58.2 & 61.7 \\
\hline Logistics & 63.3 & 63.5 & 70.9 & 65.3 & 58.3 & 66.3 & 63.2 & 70.5 & 57.9 & 65.6 \\
\hline Significance & 0.087 & 0.900 & 0.253 & 0.859 & $0.044 *$ & 0.489 & 0.543 & 0.126 & 0.628 & $\begin{array}{c}0.94 \\
0\end{array}$ \\
\hline \multicolumn{11}{|c|}{ ORGANIZATIONAL INNOVATIVENESS } \\
\hline Early adopter & 69.7 & 65.3 & 69.7 & 70.9 & 75.0 & 52.9 & 62.8 & 66.7 & 43.7 & 79.5 \\
\hline Fast follower & 59.6 & 65.7 & 57.9 & 54.3 & 63.1 & 65.8 & 61.8 & 57.4 & 59.4 & 67.4 \\
\hline Cautious follower & 59.7 & 59.6 & 64.1 & 62.2 & 58.1 & 66.8 & 57.4 & 63.2 & 63.2 & 56.3 \\
\hline Selectively agnostic & 62.7 & 61.8 & 49.2 & 57.8 & 56.2 & 44.4 & 56.4 & 59.2 & 56.9 & 63.5 \\
\hline None/other & 61.5 & 50.5 & 85.4 & 70.9 & 87.6 & 84.8 & 98.8 & 64.5 & 87.8 & 61.0 \\
\hline Significance & 0.805 & 0.519 & $0.033^{*}$ & 0.489 & 0.060 & $0.012 *$ & $0.004 * *$ & 0.836 & $0.018^{*}$ & $\begin{array}{c}0.12 \\
7\end{array}$ \\
\hline \multicolumn{11}{|c|}{ LEVEL OF INTEGRATION } \\
\hline Embedded & 55.8 & 55.8 & 57.1 & 52.8 & 54.8 & 47.2 & 56.0 & 55.6 & 55.9 & 62.3 \\
\hline Slap and ship & 54.9 & 58.2 & 55.6 & 55.6 & 51.4 & 61.9 & 54.9 & 59.9 & 51.8 & 57.3 \\
\hline Hybrid & 40.8 & 52.4 & 47.0 & 53.8 & 63.0 & 45.1 & 41.3 & 45.8 & 50.2 & 58.7 \\
\hline Don't know & 68.1 & 62.3 & 62.8 & 64.1 & 63.0 & 64.9 & 65.0 & 62.0 & 63.3 & 62.7 \\
\hline Significance & $0.026^{*}$ & 0.657 & 0.457 & 0.439 & 0.423 & $0.034^{*}$ & 0.119 & 0.383 & 0.422 & $\begin{array}{c}0.89 \\
5\end{array}$ \\
\hline
\end{tabular}

**: Significant at the 0.01 level (Asymptotic 2-tailed)

*: Significant at the 0.05 level (Asymptotic 2-tailed)

Table III: Relationships between the perceived outcomes of RFID adoption and hypothesised determining factors 


\section{Compliance with Customer Mandates}

The status of the responding organization with respect to their customer mandated use of RFID is shown in Table IV. The data in Table IV indicates that there were a number of organizations that proactively deployed RFID prior to receiving a mandate from a customer.

\begin{tabular}{lccccc}
\hline & $\begin{array}{c}\text { Retail } \\
\text { sector }\end{array}$ & $\begin{array}{c}\text { Manufacturer/processor of } \\
\text { consumer goods }\end{array}$ & $\begin{array}{c}\text { Manufacturer/processor } \\
\text { of industrial goods }\end{array}$ & $\begin{array}{c}\text { Distribution, } \\
\text { transport, logistics } \\
\text { and warehousing }\end{array}$ & $\begin{array}{c}\text { Row } \\
\text { TOTAL }\end{array}$ \\
\hline Already using & 2 & 9 & 15 & 11 & 37 \\
Now required to fulfil & 2 & 0 & 6 & 4 & 12 \\
Expecting to receive & 3 & 9 & 3 & 11 & 26 \\
Not anticipating & 5 & 6 & 23 & 17 & 51 \\
\hline TOTAL & 12 & 24 & 47 & 43 & 126 \\
\hline
\end{tabular}

Table IV: Status of the respondents with respect to RFID mandates from customers

The perceived benefits which were significantly associated with the presence of a customer mandate (in addition to the expected benefit of fulfilling this mandate) were speed of the sales cycle, and integration of data systems. Regarding the speed of the sales cycle, organizations that were now required to fulfil customer mandates had the highest Kruskal-Wallis rank (i.e. the lowest number within Table III), indicating as hypothesized, that the presence of customer mandates is negatively associated with the anticipation of other benefits. A similar phenomenon is evident with benefits relating to the integration of systems: systems integration was more likely to be anticipated as a benefit by organizations that were expected to fulfill or were expecting to receive mandates as compared to those who were already using RFID in response to customer mandates. Similarly, the association between customer mandating and anticipated cost reduction is not statistically significant suggesting that this hypothesized benefit is not (as yet, at least) carried over into practice.

The variation in anticipated ROI according to mandate status was not statistically significant ( $\mathrm{p}=$ 0.761 ) between groups. Organizations that were using RFID in response to mandates from customers were more likely, with statistical significance between groups, to have deployed RFID than those who had received or were expecting to receive mandates. This result is as hypothesised.

With respect to the hypotheses that were proposed: H1a (lower anticipated benefits for mandated RFID adopters) was partially confirmed. The anticipated benefits were viewed differently (with statistical significance between groups) for mandate compliance, speed of sales cycle and systems integration. Organizations using RFID perceived these benefits as being lower than those that had not operationalized the technology. H1b was not confirmed, due to there being no statistically significant difference between groups. H1c was confirmed: organizations with mandates are more likely to deploy RFID following trial.

\section{Industry Sector}

The only perceived benefit with a statistically significant difference between industry sectors is reduced costs $(\mathrm{p}=0.044)$, with providers of industrial goods and logistics anticipating a greater benefit. Whilst not statistically significant - at a cutoff of 5\% - between sectors, organizations in the retail sector seem to view compliance with mandates as a lesser benefit. This is due to only 
$4.4 \%$ of organizations in the sample that were mandated being classified within the retail sector. By comparison the consumer goods $(24.4 \%)$, industrial goods $(37.8 \%)$ and logistics providers (33.4\%) all had higher levels of usage due to customer mandates. Views of the different sectors on ROI did not vary, and the operational deployment of RFID did not differ significantly between industry sectors. When this last finding is coupled to the difference between sectors with respect to the application of mandates it can be inferred that whilst the level of mandates is low, use of RFID is similar Thus, the retail sector are being more proactive about the use of RFID and are not simply waiting for mandates from customers.

$\mathrm{H} 2 \mathrm{a}$ was only partially confirmed. Manufacturers of industrial goods and logistics providers viewed a reduction in costs to be the greatest anticipated benefit. $\mathrm{H} 2 \mathrm{~b}$ and $\mathrm{H} 2 \mathrm{c}$ were not confirmed, indicating that the views upon ROI are consistent across sectors with operational deployment also being similar across sectors.

\section{Perceived organizational innovativeness}

Organizations with different perceived innovativeness have statistically significant differences in views on benefits created through inventory reduction $(p=0.033)$ and price increases $(p=0.012)$. Organizations perceiving themselves as early adopters view inventory reduction to be a lesser benefit compared to organizations that perceive themselves to be followers. An increase in prices is perceived by early adopters to be of greater benefit when compared to both fast and cautious followers. Fast followers viewed the purported competitive advantage created through deployment of RFID to be a lesser benefit, albeit marginally but with strong statistical significance $(p=0.004)$, when compared to organizations with alternative perceptions of innovativeness. Early adopters anticipated greater ROI than all other organizations, with statistically significant differences between the perceptions of the organizations. There was not a significant association between innovativeness and operational deployment.

Hence, hypothesis H3a was only partially confirmed. Fast followers were not as likely to anticipate reduced inventory or competitive advantage as a benefit when compared to cautious followers. They were also more likely to view an increase in prices as a benefit. H3b was confirmed, fast followers having a more optimistic view of ROI. H3c was not confirmed as there was not a statistically significant difference between organizations of differing perceptions of innovativeness although fast followers were less likely to have deployed RFID based on the results of the Kruskal-Wallis test.

\section{Level of integration}

The level of integration between RFID technology and the existing information systems is significantly associated with the anticipated benefits of mandate compliance $(p=0.026)$ and price increase $(\mathrm{p}=0.034)$. Organizations utilizing the hybrid solution viewed mandate compliance as a greater benefit than organizations using alternative solutions, whilst organizations using the embedded and hybrid solutions viewed an anticipated increase in prices as a greater anticipated benefit. This suggests that organizations that view mandate compliance as a great benefit are partially integrating RFID into their systems, possibly to achieve some of the other benefits. Organizations utilizing slap and ship were less likely to view an increase in prices as an anticipated benefit. Views upon the ROI of RFID and level of operational deployment did not 
vary at a significant level between organizations with different levels of integration, suggesting that there is not (as yet, at least) one favored solution to the integration dilemma.

Hence, H4a was only partially confirmed due to non-significant differences in the responses for the anticipated benefits, although organizations using slap and ship viewed price increase at a statistically significant lower benefit level compared to counterparts using different solutions. $\mathrm{H} 4 \mathrm{~b}$ and $\mathrm{H} 4 \mathrm{c}$ were not confirmed as significant variance between organizations was not detected.

Summary of hypotheses

Table V summarises whether the posited hypotheses were accepted or rejected.

\begin{tabular}{|c|c|c|}
\hline Hypothesis & Description & Accept? \\
\hline $\mathrm{H}_{1 \mathrm{a}}$ & $\begin{array}{l}\text { Organizations adopting RFID in response to a customer mandate will have lower anticipated } \\
\text { benefits than those who have not received a mandate. }\end{array}$ & Partially \\
\hline $\mathrm{H}_{1 \mathrm{~b}}$ & $\begin{array}{l}\text { Organizations adopting RFID in response to a customer mandate will have a lower anticipated } \\
\text { ROI than those who have not received a mandate. }\end{array}$ & No \\
\hline $\mathrm{H}_{1 \mathrm{c}}$ & $\begin{array}{l}\text { Responding to a customer mandate will positively determine whether organizations have } \\
\text { progressed beyond a trial to operational deployment of RFID. }\end{array}$ & Yes \\
\hline $\mathrm{H}_{2 \mathrm{a}}$ & $\begin{array}{l}\text { Anticipated benefits derived from adopting RFID technology will be determined by the industry } \\
\text { sector in which the organization resides. }\end{array}$ & Partially \\
\hline $\mathrm{H}_{2 \mathrm{~b}}$ & $\begin{array}{l}\text { ROI derived from adopting RFID technology will be determined by the industry sector in which } \\
\text { the organization resides. }\end{array}$ & No \\
\hline $\mathrm{H}_{2 \mathrm{c}}$ & $\begin{array}{l}\text { Organizations operationally deploying RFID will be determined by the organization's industry } \\
\text { sector. }\end{array}$ & No \\
\hline $\mathrm{H}_{3 \mathrm{a}}$ & $\begin{array}{l}\text { Anticipated benefits from adopting RFID will be dependent on the perceived innovativeness of the } \\
\text { adopting organization. }\end{array}$ & Partially \\
\hline $\mathrm{H}_{3 \mathrm{~b}}$ & $\begin{array}{l}\text { Anticipated ROI deriving from adopting RFID will be dependent on the perceived innovativeness } \\
\text { of the adopting organization. }\end{array}$ & Yes \\
\hline $\mathrm{H}_{3 \mathrm{c}}$ & $\begin{array}{l}\text { The decision to adopt RFID operationally will be dependent on the perceived innovativeness of } \\
\text { the adopting organization. }\end{array}$ & No \\
\hline $\mathrm{H}_{4 \mathrm{a}}$ & $\begin{array}{l}\text { Organizations employing a slap and ship adoption strategy will have lower anticipated benefits } \\
\text { than those integrating RFID with their existing information systems. }\end{array}$ & Partially \\
\hline $\mathrm{H}_{4 \mathrm{~b}}$ & $\begin{array}{l}\text { Organizations employing a slap and ship adoption strategy will have lower anticipated return on } \\
\text { investment than those integrating RFID with their existing information systems. }\end{array}$ & No \\
\hline $\mathrm{H}_{4 \mathrm{c}}$ & $\begin{array}{l}\text { A greater proportion of organizations that have adopted a slap and ship adoption strategy will have } \\
\text { progressed beyond a trial to operational deployment than those organizations that have an } \\
\text { integrated approach. }\end{array}$ & No \\
\hline
\end{tabular}

Table V: Summary of evidence for hypotheses

\section{DISCUSSION}

The first survey finding relating the presence of a mandate to anticipated speed of sales cycles suggests that some benefits of using RFID accrue from an interorganizational relationship where the mandating customer has also adopted the technology (whilst this was not asked in the survey, it is assumption we have made given that there would be no reason for a mandate to be issued if the customer did not have the technology in place to exploit it). This suggests that for certain benefits a "go it alone strategy" will not be sufficient and the RFID implementations require a collaborative approach. This has a broader implication for how the whole supply chain is managed, and in particular for the relationship dynamic that is in operation. Moreover, the relationship between customer mandates and integration of RFID technology with the wider information system infrastructure suggests that decisions about RFID cannot be made in isolation from other functions and their information systems any more than from customers. 
The second finding that the presence of mandates leads to greater level of deployment reveals a key characteristic of the adoption of RFID. These findings suggest that without outside pressure, fewer organizations will move from a trial to full operational deployment of RFID. It is clear as to why mandated organizations move to operational deployment - a necessary order qualifier. However, concerning those without a mandate, the findings from hypothesis $\mathrm{H}_{1 b}$ conclude that the presence of a mandate does not have a role in determining whether or not a return on an investment is anticipated. Why is this so? Simply having a mandate does not mean an ROI will be generated. Hence the ROI may be related to other factors found in previous research into the adoption of new technologies: size of the company (Galbraith, 1956; Bajwa and Lewis, 2003) top management support (Teo, et al., 1997; Hambrick and Mason, 1984; Mitropoulos and Tatum, 1999; O'Niell, et al, 1998) existence of a champion (Hoffman et. al., 1996; Maxwell and Westerfield, 2002), internal needs (Chen, 2003; Rogers, 2003) and so on. We suggest that these factors need to be taken into account when other scholars conduct research into the adoption of this technology.

The study identified that industrial manufacturers and logistics and transportation organisations expect to reduce costs more than retailers and consumer goods manufacturers. This focus on cost may be explained by the absence of mandates in these sectors and a more internally motivated rationale for RFID adoption. Apart from costs, this study finds no difference across the sectors in the ROI that is anticipated or in the extent of operational deployment. It appears that benefits are possible for organizations from all sectors, and that what determines whether or not a ROI can be generated, and consequently whether a trial can progress to full scale deployment, may be other factors such as the type of application.

Finally, there is no relationship of perceived organisational innovativeness on whether RFID benefits are accrued, whether ROI is generated or whether trials progress to operational deployment. This could be due to organizations perceiving the technology to be a continuous technology - an evolution of bar codes - as opposed to a discontinuous one (Christensen, 1997, Utterback, 1996). It seems that the capability to undertake a successful RFID implementation is not dependent on internal innovativeness and the lack of this is not a barrier to deriving benefits from the technology and progressing beyond a trial to operational deployment.

\section{CONCLUSIONS}

We have presented the results of a survey conducted with 612 European supply chain managers, analyzing responses from 128 of these managers who had experience of adopting RFID technology. This paper sought to ascertain the impact on RFID trial success of four determining factors: the presence of customer mandates; the organization's industry sector; the self-perceived level of organizational innovativeness; and the level of integration between RFID and the organizations other information systems. The results show that the presence of mandates from customers leads to adopting organizations moving from a trial to operational deployment. Given that many retailers have made the use of RFID an "order qualifier" this result is to be expected. Further, faster sales cycles appear to be linked to the presence of mandates, indicating that RFID may provide some competitive benefit for adopting suppliers, though the link seems a complex one. 
The second major finding is that logistics and transportation companies and industrial manufacturers expect RFID to result in cost reductions for them. This could reflect the different motivational drivers for these two sectors. Not being subject to mandates from their customers, these early adopters may have been motivated by internal needs, including cost reduction, more than external factors such as customer service. The challenge for these two groups now is to consider whether or not they could achieve the benefits accrued by the other groups as a secondary benefit.

We found no relationship between perceived organizational innovativeness and RFID adoption, which could be due to the perception of RFID only being an evolutionary progression from barcode technology, rather than a radical or discontinuous technology, at least as it is being applied in a supply chain context. Finally, the level of IS integration employed by adopting organizations did not have an effect on the outcomes achieved. This may indicate that there are certain conditions under which all three IS integration strategies - full integration, 'slap and ship' and a hybrid of the two - are appropriate.

This study has a number of limitations, the first of which are the geographic and industry sector foci. Secondly, this is a fast moving field of research, where practice often moves faster than theory is able to keep up: further qualitative research to explore emergent benefits and factors influencing adoption would help to frame future survey work. Specifically, we believe further exploratory research is needed into the specific RFID applications that are being employed in the context of supply chains, and specifically, what benefits are they accruing, what levels of ROI are being generated and which applications are becoming assimilated into everyday operations. Another specific topic we hope future researchers will consider is exploration of the factors which determine whether a slap and ship or fully integrated approach is required. Future survey work will be aided by the greater rates of adoption that can be expected with time, and hence by greater sample sizes of early adopters, which would increase the statistical power of tests and therefore the likelihood of identifying adoption factors which are, in fact, present. And finally, this paper has not investigated those that have not adopted this technology at all and their reasons for not having as yet planned RFID trials: this is an important area for future research, which might draw on such precedents as Shih and Venkatesh (2004) who examined factors influencing adoption and factors influencing the success of that adoption in a single, integrated model.

\section{REFERENCES}

Aberdeen Group (2004). RFID in the consumer industries, www.aberdeen.com.

Accenture (2004). High performance enabled through Radio Frequency Identification, www.accenture.com

Alkadi, I., Alkadi, G., and Totaro, M. (2003). Effects of information technology on the business world, Human Systems Management, Vol. 22, No. 3, pp. 99-103.

Angeles, R. (2005). RFID technologies: supply chain application and implementation issues, Information Systems Management, Vol. 22, No. 1, pp. 51-65. 
Asif, Z. and Mandviwalla, M. (2005). Integrating the supply chain with RFID, Communications of the Association of Information Systems, Vol. 15, pp. 393-427.

Atkinson, W. (2004). Tagged: The risks and rewards of RFID technology, Risk Management, Vol. 51, No. 7, pp. 12-19.

Attaran, M. (2007). RFID: an enabler of supply chain operations, Supply Chain Management: an International Journal, Vol. 12, No. 4, pp. 249-257.

Ault, A. (2004). US FDA calls for technological attack on drug counterfeiting, The Lancet, Vol. 363, pp. 714.

Auramo, J., Aminoff, A. and Punakivi, M. (2002). Research agenda for e-business logistics based on professional opinions, International Journal of Physical Distribution and Logistics Management, Vol. 32, No. 7, pp. 513-531.

Avlonitis, G., Kouremenos, A. and Tzokas, N. (1994). Assessing the innovativeness of organizations and the antecedents, European Journal of Marketing, Vol. 28, No. 11, pp. 5-28.

Bajwa, D and Lewis, L., 2003. Does size matter? An investigation of collaborative information technology adoption by US firms, Journal of Information Technology Theory and Applications, Vol. 5, No. 1, pp. 29-46.

Biemer P.P. and Lybergy, L.E. (2003). Introduction to Survey Quality. New Jersey: WileyInterscience.

Brandbyberry A., Rai, A., and White, G.P. (1999). Intermediate performance impacts of advanced manufacturing technology systems: an empirical investigation, Decision Sciences, Vol. 30, No. 4, pp. 993-1020.

Breu, K. and White, A. (2004). The coming of the ubiquitous organisation; an essay on the Emergence of a new organisational paradigm, Revue Sciences de Gestion, Vol. 40, pp. 217235.

Byrd, T.A. and Davidson, N.W. (2003). Examining possible antecedents of IT impact on the supply chain and its effect on firm performance, Information and Management, Vol. 41, No. 2, pp. 243-255.

Cavinato, J. (2005). Supply chain logistics initiatives: research and applications, International Journal of Physical Distribution and Logistics Management, Vol. 35, No. 3, pp. 148-151.

Chen, M., (2003). Factors affecting the adoption and diffusion of XML and Web services standards for e-business systems, International Journal of Human-Computer Studies, Vol. 58, No. 3, pp. 259-279. 
Chow, H., Choy, K.L., Lee, W.B. and Chan, F.T.S. (2007). Integration of web-based and RFID technology in visualizing logistics operations - a case study, Supply Chain Management: an International Journal, Vol. 12, No. 3, pp. 221.

Christensen, C. (1997). The innovators dilemma. USA: Harvard Business School Press.

Christopher, M. (1998). Logistics and Supply Chain Management, Financial Times, UK.

Christopher, M. (2004). Understanding supply chains: a marketing perspective, in New, S. and Westbrook, R. (Eds.), Understanding Supply Chains: Concepts, Critiques \& Futures, Oxford University Press, Oxford, pp. 23-42.

Clarke, R. (1992). A contingency model of EDI's impact on industry structures, Journal of Strategic Information Systems, Vol. 1, No. 3, pp. 143-151.

Dewberry, C., 2004. Statistical Methods for Organizational Research: Theory and Practice. Abingdon, Oxford: Routledge.

Dominy, M., (2003), Collaborative and optimized inbound logistics, Yankee Group, www.yankeegroup.com.

Ellram. L.M., La Monde, B.J. and Weber, M.M. (1989). Retail logistics, International Journal of Physical Distribution \& Logistics Management, Vol. 19, No.12; pp. 29 - 40.

Ellram, L.M. (1996). The use of the case study method in logistics research. Journal of Business Logistics, Vol. 17, No. 2, pp. 93-138.

Feenstra, R.C. (1998). Integration of trade and disintegration of production in the global economy. Journal of Economic Perspectives, Vol. 12, No. 4, pp. 31-50

Forrester, J. 1961. Industrial Dynamics, MIT Press, and John Wiley \& Sons, Inc., New York

Fisher, M.L. (1997). What is the right supply chain for your product? Harvard Business Review, Vol. 75, No. 2, pp. 105-116.

Frisk.L., Jarvinen, J. and Ristolainen, R. (2002). Chip on flex attachment with thermoplastic ACF for RFID applications, Microelectronics Reliability, Vol. 42, pp. 1559-1562.

Frohlich, M.T., (2002). e-integration in the supply chain: barriers and performance, Decision Sciences, Vol. 33, No. 4, pp. 537-556.

Galbraith J., 1956. American capitalism (Rev. ed.), Houghton Mifflin, Boston.

Gunasekaran, A. and Ngai, E. (2004). Information systems in supply chain integration and management, European Journal of Operational Research, Vol. 159, pp. 269-295. 
Hambrick, D., and Mason, P., (1984). Upper echelons: The organization as a reflection of its senior managers, Academy of Management Review, Vol. 9, No. 2, pp. 193-206.

Hoffman, D. and Novak, T., (1996). Marketing in hypermedia computer-mediated environments: conceptual foundations. Journal of Marketing, Vol.60, pp. 50-68.

Hult, G., Hurley, R. and Knight, G. (2004). Innovativeness: its antecedents and impact on organizational performance, Industrial Marketing Management, Vol. 33, pp. 439-438.

Jayaram, J., Vickery, S.K. and Droge, C. (2000). The effects of information system infrastructure and process improvements on supply chain time performance, International Journal of Physical Distribution \& Logistics Management, Vol. 30, No. 3/4, 314-327.

Jones, P., Clarke-Hill, C., Hillier, D. and Comfort, D. (2005). The benefits, challenges and impacts of radio frequency identification technology for retailers in the UK, Marketing Intelligence \& Planning, Vol. 23, No. 4/5, pp. 395-402.

Jones, P., Clarke-Hill, C., Shears, P., Comfort, D. and Hillier, D. (2004). Radio frequency identification in the UK: opportunities and challenges, International Journal of Retail and Distribution Management, Vol. 32, No. 2/3, pp. 164-171.

Juniper (2005). RFID Futures in Western Europe, www.juniper.com

Kearns, G. (2004). A multi-object, multi-criteria approach for evaluating IT investments: Results from two case studies, Information Resources Management Journal, Vol. 17, No. 1, pp. 37-62.

Kent, J.L. and Mentzer, J.T. (2003). The effect of investment in interorganizational information technology in a retail supply chain, Journal of Business Logistics, Vol. 24, No. 2, pp. 1155-175.

Kincade, D.H., Vass, D., and Cassill, N.L. (2001). Implementation of technology and relationships to supply chain performance: apparel manufacturers' perspectives, International Review of Retail, Distribution and Consumer Research, Vol. 13, No. 3, pp. 301-327.

King, W.R. (2002). IT capabilities, business processes, and impact on the bottom line. Information Systems Management Vol. 19, No. 2 pp. 85-87.

Knospe, H. and Pohl, H. (2004). RFID security, Information Security Technical Report, Vol. 9, No. 4, pp. 39-50.

Kotha, S. and Swamidass, P.M. (2000). Strategy, advanced manufacturing technology and performance: empirical evidence from US manufacturing firms, Journal of Operations Management, Vol. 18, No. 3, pp. 257-277. 
Lee, H., Padmanabhan, P and Whang, S. (1997). The bullwhip effect in supply chains, Sloan Management Review, Vol. 38, No. 3, pp. 93-102.

Lee, H.L. (2002). Aligning supply chain strategies with product uncertainties. California Management Review, Vol. 44, No. 3, pp. 105-119.

Lee, H.L. and Billington, C. (1992) Managing supply chain inventory: pitfalls and opportunities. Sloan Management Review, Vol. 33, No. 3, pp. 65-73.

Lee, S.C. (2001). Modeling the business value of information technology, Information \& Management, Vol. 39, pp. 191-210.

Li, T. and Calantone, R. (1998). The impact of market knowledge competence on new product advantage: conceptualisation and empirical examination. Journal of Marketing, 62(Oct), 13-29.

Lin, D., Barton, R., Bi, H. and Freimer, M. (2006). Challenges in RFID enabled supply chain management, Quality Progress, Vol. 39, No. 11, pp. 23-27.

LogicaCMG, (2004). Airbus takes RFID into the spare parts supply chain, White Paper, available at www.logicacmg.com

Malone, T., Yates, J. and R. Benjamin, (1987). Electronic markets and electronic hierarchies, Communications of the ACM, Vol. 30, No. 6, pp. 484- 497.

Maselli, J. (2003). RTLS drives efficiencies at BMW, RFID Journal, November $28^{\text {th }}$.

Maxwell, J. and Westerfield, D., (2002). Technology entrepreneurism characteristics related to the adoption of innovative teechnology, SAM Advanced Management Journal, Vol. 67, No. 1, pp. 9-21.

McFarlane, D. and Sheffi, Y. (2003). The impact of automatic identification on supply chain operations. The International Journal of Logistics Management, Vol. 14, No. 1, pp. 1-17.

Miller, J. (2007). Criteria for evaluating RFID solutions for records and information, Information Management Journal, Vol. 41, No. 1, p. 50-54.

Mitropoulos, P. and Tatum, C., (1999). Technology adoption decisions in construction organizations, Journal of Construction Engineering and Management, September/October, pp. 330-338.

Nagumo, T. (2002). Innovative business models in an era of ubiquitous networks, Nomura Research Institute. Japan. 
O'Neill, H., Pouder, R., and Buchholtz, A., (1998). Patterns in the diffusion of strategies across organizations: insights from the innovation diffusion literature, Academy of Management Review, Vol. 21, No. 1 pp. 98-114.

Parasuraman, A., Zeithmal, V.A. and Berry, L. (1985). A conceptual model of service quality and its implications for future research, Journal of Marketing, Vol. 49, pp. 41-50

Porter, M.E. (1985). Competitive Advantage: creating and sustaining superior performance, Free Press, New York, USA.

Rasul, J. (2004). Chip on paper technology utilizing anisotropically conductive adhesive for smart label applications, Microelectronics Reliability, Vol. 44, pp. 135-140.

Rogers, E.M. (2003) Diffusion of Innovations, 4th ed. Free Press, New York.

Sheffi, Y. (2004) RFID and the innovation cycle. The International Journal of Logistics Management, Vol. 5, No. 1, pp. 1-10.

Shih, C.-F. and Venkatesh, A. (2004) Beyond adoption: development and application of a use-diffusion model. Journal of Marketing, 68(1), 59.

Siegel, S. (1956). Nonparametric statistics for the behavioral sciences. New York: McGrawHill

Sullivan, L. (2004). European retailers accelerate RFID plans, Information Week, January $24^{\text {th }}$.

Tang, H.K. (1999). An inventory of organizational innovativeness, Technovation, Vol. 19, pp. 41-51.

Teo, T., Tan M. and Buk K., (1997). A contingency model of Internet adoption in Singapore, International Journal of Electronic Commerce, Vol. 22, pp. 57-69.

Themistocleous, M., Irani, Z. and O'Keefe, R. (2001). ERP application and integration, Business Process Management Journal, Vol. 7, No. 3, pp. 195-204.

Tiernan, P. and Peppard, J. (2004). Information technology: of value or a vulture, European Management Journal, Vol. 22, No. 6, pp. 609-623.

Twist, D.C. (2005). The impact of radio frequency identification on supply chain facilities, Journal of Facilities Management, Vol. 3, No. 3 pp. 226-239.

Utterback, J. (1996). Mastering the dynamics of innovation. USA: Harvard Business School Press. 
Vijayaraman, B.S. and Osyk, B.A. (2006). An empirical study of RFID implementation in the warehousing industry, The International Journal of Logistics Management, Vol. 17 No. 1, pp. 6-20

Williams, T. (1997). Interorganizational information systems: issues affecting interorganizational cooperation, Journal of Strategic Information Systems, Vol. 6, No. 3, pp. 231-250.

Wise, R. and Baumgartner, P. (1999). Go downstream: the new profit imperative in Mmanufacturing. Harvard Business Review, Vol. 77, No. 5, pp. 133-141.

Wyld, D.C., Jones, M.A.and Totten, J.W. (2005). Where is my suitcase? RFID and airline customer service, Marketing Intelligence \& Planning, Vol. 23, No. 4/5, pp. 382-394.

Yagi, J., Arai, E., Arai, T. (2005). Parts and packets unification for radio frequency identification for construction, Automation in Construction, Vol. 14, pp. 477-490.

Yang, J. and Papazoglou, M.P., (2000). Interoperation support for electronic business, Association for Computing Machinery, Vol. 43, No. (6), pp. 39-47.

\title{
APPENDIX: Note on the Kruskal-Wallis test
}

The Kruskal-Wallis (K-W) test is a one-way analysis of variance by ranks to determine whether $k$ independent samples come from different populations. It is a non-parametric equivalent of Analysis of Variance (ANOVA). The K-W test assumes that the variable being studied has an underlying continuous distribution, therefore any survey instrument should use at least ordinally scaled items. The computation of the K-W test involves the replacement of each of the $N$ observations. For example the lowest score is replaced by rank 1, the second lowest by rank 2 and the highest by rank $N$. When this has been performed the sum of the ranks in each sample is computed with the $\mathrm{K}-\mathrm{W}$ test determining whether the sums of ranks are disparate according to a chi-square distribution.

\begin{abstract}
About the authors
Andrew White

Dr. Andrew White is a Fellow in Strategic Innovation at Said Business School, University of Oxford. His research focuses on understanding how organizations can successfully manage innovation, particularly discontinuous innovation. He has published in several international academic and practitioner journals, such as the European Journal of Information Systems and Technovation, and presented at numerous international conferences. He acts as a consultant to a number of global organizations, and has recently co-authored a review of how information technology will create intelligent infrastructure systems over the next few decades for the UK Government's Department of Trade and Industry. He is a Fellow of the Royal Society for the Encouragement of Arts, Manufacturers \& Commerce and has recently been appointed as a Scholar with the Advanced Institute of Management Research, a UK government initiative that
\end{abstract}


aims to exemplify how collaborative management research and development can contribute to academic, business, public service and policy audiences.

\section{Mark Johnson}

Mark is a member of the Supply Chain Research Centre at Cranfield School of Management . Mark's current research portfolio includes a two year project, co-funded by Rolls-Royce and the DTI, that is aimed at improving supply chain planning and control practices. Mark is also a member of Cranfield University's Innovative Manufacturing Research Centre's Product-Service Systems initiative. Mark directs Cranfield's Agile Supply Chain Research Club, a forum of 15 blue-chip organisations which develops insights into the complexity of today's supply chain environments. Mark has also performed research with Atos Origin on the drivers of servitization, PA Consulting Group on the impact of supply chain performance on organizational performance, GVA Grimley / ProLogis on the structural differences of the UK manufacturing and distribution sectors and NESTA / Department of Business, Environment and Regulatory Reform on Innovation within the UK Logistics Sector.

\section{Hugh Wilson}

Hugh Wilson is Professor of Strategic Marketing and Director of the Centre for Customer Management at Cranfield School of Management. Hugh is listed in the Chartered Institute of Marketing's global 'Guru Gallery' of 'the 50 leading marketing thinkers alive today'. Hugh has a mathematics degree from Oxford University, a postgraduate computer science degree from Cambridge University and a prize-winning $\mathrm{PhD}$ in marketing planning from Cranfield. He has extensive industrial experience, including thirteen years in the IT industry. His books include 'The New Marketing' (2002) and 'The Multichannel Challenge' (2008). He has published in Industrial Marketing Management, European Journal of Marketing, Journal of Strategic Information Systems and British Journal of Management amongst others. He was recently honoured by the DTI as one of the "Internet Decade" list of the hundred individuals who have had most influence over the development of e-commerce, according to an NOP poll of practitioners. 